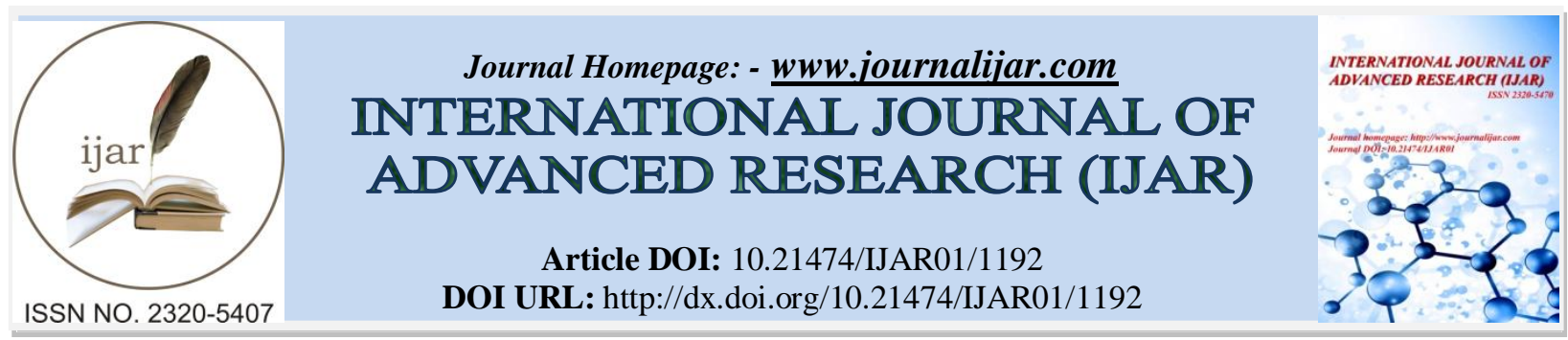

RESEARCH ARTICLE

\title{
AUXIN AND CYTOKINE TREATMENT EFFECT IN COMBINATION WITH SUCROSE ON IN VITRO POTATO REGENERATION.
}

Iveta Megrelishvili, Ekaterine Bulauri, Tamar Chipashvili and Maia Kukhaleishvili. Georgian Technical University, Biotechnology Center, 0156, Tbilisi, Georgia.

\section{Manuscript Info}

Manuscript History

Received: 15 June 2016

Final Accepted: 19 July 2016

Published: August 2016

Key words:-

In vitro, de novo shoot formation, root formation, auxin, cytokine, Indole-3 butyric acid (IBA), and 6-

Benzylaminopurine (BAP).

\begin{abstract}
In this study we focused on in vitro potato regeneration under different hormonal (auxin/cytokine) treatment with combination of sucrose in three potato varieties, "Nevsky, Riviera, Zefira". Three parameters were observed in response to treatment, number of shoots development, size of shoots, and root length. In vitro tissue culture propagation of three potato cultivars (Solanum tuberosumL.) "Nevsky", Zefira" and "Riviera" were studied on modified MS medium supplemented with hormones (IBA/BAP) concentration: $\mathrm{MS}+30 \mathrm{~g} / \mathrm{l}$ sucrose $(6 \% \mathrm{MS}$ medium), $6 \% \mathrm{MS}$ medium $+1 \mathrm{mg} / \mathrm{l} \mathrm{BAP}+0,05 \mathrm{mg} / \mathrm{l} \mathrm{IBA}$ and $6 \% \mathrm{MS}$ medium $+1 \mathrm{mg} / \mathrm{l}$ BAP $+0,1 \mathrm{mg} / \mathrm{l}$ IBA. Morphological characterization of all three in vitro potato cultivars on modified MS medium was variable depending on varieties.It was revealed that high concentration of IBA has negative effect on plants development, respectively 6\% MS medium $+1 \mathrm{mg} / \mathrm{l} \mathrm{BA}+0,1 \mathrm{mg} / \mathrm{l} \mathrm{IBA}$ was not optimal neither cultivars of potato. According to the results cultivars Zefira" and "Riviera" had maximum potential for in vitro rooting ( correspondingly: $82.97 \%$ and $100 \%$ ) and shoots (100\% and $87.34 \%$ ) formation on $6 \%$ MS medium $+1 \mathrm{mg} / \mathrm{l} \mathrm{BA}+0,05 \mathrm{mg} / \mathrm{l}$ IBA, but "Nevsky" gave maximum development (rooting-82\% and shoot formation $-87 \%$ ) on $6 \%$ MS medium.
\end{abstract}

Copy Right, IJAR, 2016,. All rights reserved.

\section{Introduction:-}

Potatoes are a widespread culture. According to FAO data potatoes are grown in 180 countries through the world, in line with 2005 data 202974000 tons of potatoes were consumed in the world. From 1991 to 2007 years potato production increased 267.99- 325.30million tons (FAOSTAT Agriculture (2016).

In terms of consumption potato is the major crop in Georgia. In spite of diverse climatic conditions of Georgia, potato is high spreading culture mountain regions in Georgian, drought -resistant ability of potato enable us to produce as food (early and late) as seed potatoes. Recently in vitrotissue cultures become wider and significant in Georgian agriculture production and development. In vitropotato plantlets derived meristem culture technique are free from the risk of spreading bacteria, fungiand insect transmitted virus, in vitroregeneration protocol was establish in many laboratories in the world but still there is (or more study needs to be done about which potato genotypes are more efficient for in vitro tissue culture propagation) less information about which potatoes genotypes is more 
efficient for propagated vegetative by in vitro tissue culturetechnique need to be study (Naik and Sarkar, 2000, Karim, 2009).

In vitroplant reproduction widely used in agriculture and biotechnology and has a great advantage compared to traditional breeding methods: A) allows to obtain get virus-free planting material in a short-term. B) plant reproduction can be conducted throughout the year, without a break for transformation $\mathrm{t}$ (Khan et al., 2003, Wang and Hu, 1982, Islam and Chowdhury, 1998, Espinoza at al., 1986, Liljana at al., 2012).

For potato in vitro regeneration mainly are used Murashige-Skooge (MS) medium. one group of researchers adopt hormone free MS medium for in vitro plant production in vitro plants are grown on hormone free MS medium on the other hand studies are done on the effect of different combination of growth hormones for in vitro potato reproduction(Badoni and Chauhan, 2009).

Growth regulators play an important role in potato regeneration, it should be noted that growth hormones on potato sprout explants are characterized different effects according to potato varieties, it depends on their genetics and endogenous hormones concentration (Khadiga at al., 2009, Kaur at al., 2015, Kumlay, 2014).

Our research group is working in vitro tissue culture potato plant breeding, we have 52 different varieties in the center that's allows as to study genotype differences on in vitro potato production and farther adaptation in the field, the aim of the research was to find out and set a new protocol for test tube potato production for the varieties that are most used in Georgia agriculture production.

Our research center is working successfully on test-tube potato plant breeding, we have 52 varieties in our in vitrocollection.

The present investigation was carried out to select best MS medium protocol and identify perfect hormonal/sucrose combination for three varieties of potato: "Nevski", "Riviera" and "Zefira" for their invitrocultivation.

\section{Material and Methods:-}

Plant material and growth conditions:-

Three potato variety Nevsky", Riviera" and "Zefirawas used for in vitro propagation experiment at tissue culture laboratory of Georgian Technical University

Biotechnological Center. These diversities of potatoes have been selected in the interests of the Georgian farmers. The three varieties were tested for in vitro response under high levels of sucrose and two different combinations of growth hormones:

\section{Medium composition and hormonal treatment:-}

1. MS medium $+30 \mathrm{~g} / \mathrm{l}$ sucrose $(6 \% \mathrm{MS}$ medium)

2. $6 \% \mathrm{MS}$ medium $+1 \mathrm{mg} / \mathrm{l} \mathrm{BA}+0,05 \mathrm{mg} / \mathrm{l} \mathrm{IBA}$

3. $6 \% \mathrm{MS}$ medium $+1 \mathrm{mg} / \mathrm{l} \mathrm{BA}+0,1 \mathrm{mg} / \mathrm{l} \mathrm{IBA}$

As a control we use basal MS medium ((Murashigeand Skoog, (MS) 1962), the pH of the medium was adjust 5.8, agar $(7 \mathrm{~g} / \mathrm{l})$ was added into the medium and the medium was autoclaved at $121^{\circ} \mathrm{C}$ for 20 minutes at $15 \mathrm{psi}$. MS basal medium containing $30 \mathrm{~g} / \mathrm{l}$ sucrose. All the surface sterilization procedures were carried out under sterile condition of laminar flow chamber, 4 week old explant were dissected into single nodes $(2-3 \mathrm{~cm} \mathrm{long})$ on a sterile plate. The excised explants were cultured into culture medium in tube and incubated under 16 hour photoperiod at $25-26^{\circ} \mathrm{C}$ with a light intensity of 2500 lux. The sprouts were allowed to grow into plantlets having nodal segments for 3 to 4 weeks.

Best combination of medium for each potato cultivars was selected for their stem height, thickness, amount of nodes per plant and rooting (\%) after 4 weeks. 


\section{Result and Discussion:-}

In vitro cultivation of potato varieties was studied on three different MS medium, sucrose, IBA and BAP concentration were examined in detail.

The sucroseinfluences on three in vitropotato cultivar's (Nevsky, Riviera, Zefira)rooting and shoots formaton is presented in Table 1.

Table 1:- The effect of sucrose on in vitro potato shoots and roots regeneration.

\begin{tabular}{|c|c|c|c|c|c|c|c|}
\hline $\begin{array}{c}\text { potato } \\
\text { Cultivars }\end{array}$ & Plant type & Shoot length (mm) & $\begin{array}{c}\text { Shoot } \\
\text { thickness } \\
\text { (mm) }\end{array}$ & $\begin{array}{c}\text { Nodes } \\
\text { per } \\
\text { plant }\end{array}$ & $\begin{array}{l}\text { Root } \\
\text { length } \\
(\mathrm{mm})\end{array}$ & Rooting (\%) & $\begin{array}{c}\text { Shoot } \\
\text { formation } \\
(\%)\end{array}$ \\
\hline \multicolumn{8}{|c|}{ MS medium+30mg/l sucrose( $6 \%$ MS medium) } \\
\hline Nevsky & in vitro plant & 140 & 2 & 9 & 22 & 100 & 98 \\
\hline Riviera & in vitro plant & 50 & 0.8 & 2 & 0.5 & 18 & 15 \\
\hline Zefira & in vitro plant & 110 & 1.8 & 7 & 14 & 82 & 87 \\
\hline
\end{tabular}

The results showed that the Nevsky has maximum potential for in vitro rooting and shoots formation on basal MS medium $+30 \mathrm{mg} / \mathrm{l}$ sucrose ( $6 \%$ MS medium) among the three different genotype of potato, All parameters revealed optimal formation: $100.00 \%$ rooting, high and strength shoot formation $(98 \%)$ with 9 nodes per plant, but Riviera had a weak in vitro development (rooting-18\% and shoot formation- 15\% with only 2 nods) on 6\% MS medium (Figure 1).

It is known that auxin/ cytokine combination has varies result on in vitro morphogenetic response (Morariu at al., 2010). On next stage of research on 6\%MS medium was supplemented cytokine 6-Benzylaminopurine (BAP) and auxin Indol-3-butiric acid (IBA). Only one concentration of BAP was used (1mg/l), but two concentrations of IBA $(0,05 \mathrm{mg} / \mathrm{l}$ and $0,1 \mathrm{mg} / \mathrm{l})$ was selected for experiment.
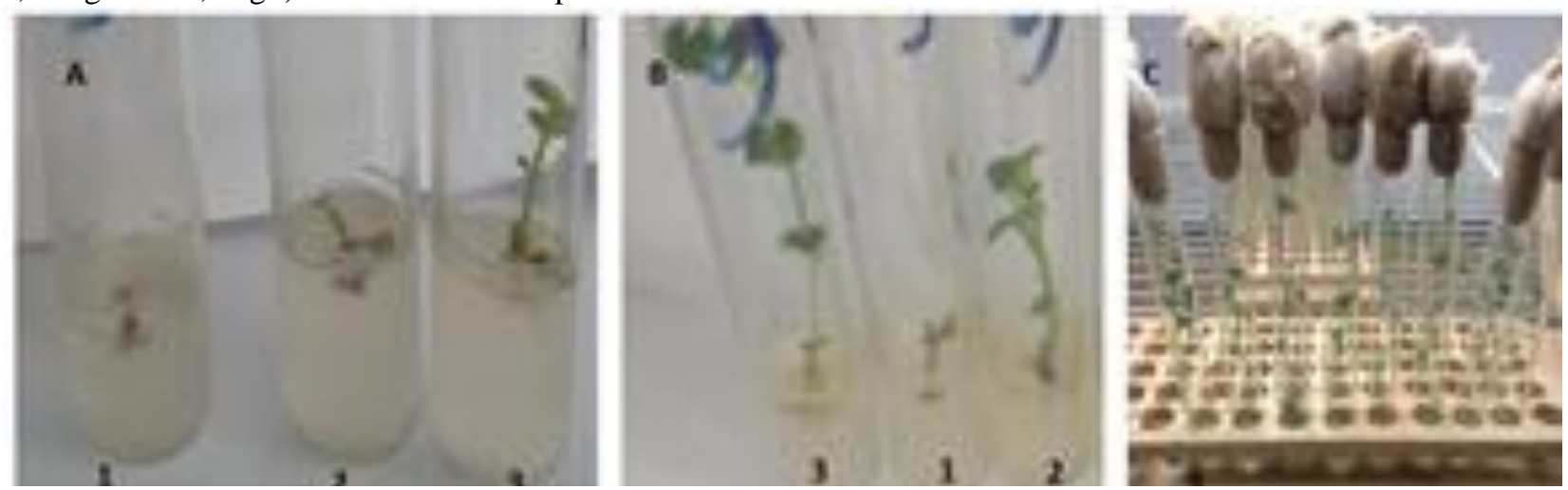

Figure 1:- Sucrose effect on three potato cultivar's(Nevsky, Riviera, Zefira) in vitropropagation A- after 2 weeks (1-Riviera, 2-Zefira, 3-Nevsky) B-after 3 weeks (1-Riviera, 2-Zefira, 3- Nevsky) C-after 4 weeks (3- Nevsky) , 1Riviera, 2-Zefira, 3- Nevsky

There is presented influence of IBA $(0.05 \mathrm{mg} / \mathrm{l})$ and $\mathrm{BAP}(1 \mathrm{mg} / \mathrm{l})$ on in vitro roots and shoots formation which depends on potato cultivars in the table 2.De novo shoot formation and rooting percentage in "Nevsky" genotype Cytokine/auxin combination (1mg/lBAP/0,05mgIBA)was not effective to compare 6\% MS medium without growth hormoneswhereas in vitro regeneration of potato cultivars- Zefira and Riviera testified improved on 6\% MS medium containing BAP and IBA,Zefira showed maximum rooting and shoot formation (both parameters $-100 \%$ and 100\%) and strength shoots with 9 nods.Riviera revealed in vitro rooting andshoot formation correspondingly: $83 \%$ and $87.34 \%$ with 6 nods. (Figure 2.) 
Table 2:- The effect of cytokine IBA $(0.05 \mathrm{mg} / \mathrm{l})$ and auxin BAP $(1 \mathrm{mg} / \mathrm{l})$ in vitro potato cultivar's shoots and roots formation.

\begin{tabular}{|c|c|c|c|c|c|c|c|}
\hline $\begin{array}{c}\text { Potato } \\
\text { Cultivars }\end{array}$ & Plant type & Shoot length (mm) & $\begin{array}{c}\text { Shoot } \\
\text { thickness } \\
(\mathrm{mm})\end{array}$ & $\begin{array}{c}\text { Nodes } \\
\text { per } \\
\text { plant }\end{array}$ & $\begin{array}{c}\text { Root } \\
\text { length } \\
(\mathrm{mm})\end{array}$ & rooting (\%) & $\begin{array}{c}\text { Shoot } \\
\text { formation } \\
(\%)\end{array}$ \\
\hline \multicolumn{7}{|c|}{$6 \%$ MS medium+ 1mg/l BAP + 0,05mg/l IBA } \\
\hline Nevsky & in vitro plant & 91 & 1.21 & 5 & 16.42 & 68.5 & 66.74 \\
\hline Riviera & in vitro plant & 112.14 & 1.57 & 6 & 12.23 & 83 & 87.34 \\
\hline Zefira & in vitro plant & 147 & 2.67 & 9 & 23.56 & 100 & 100 \\
\hline
\end{tabular}
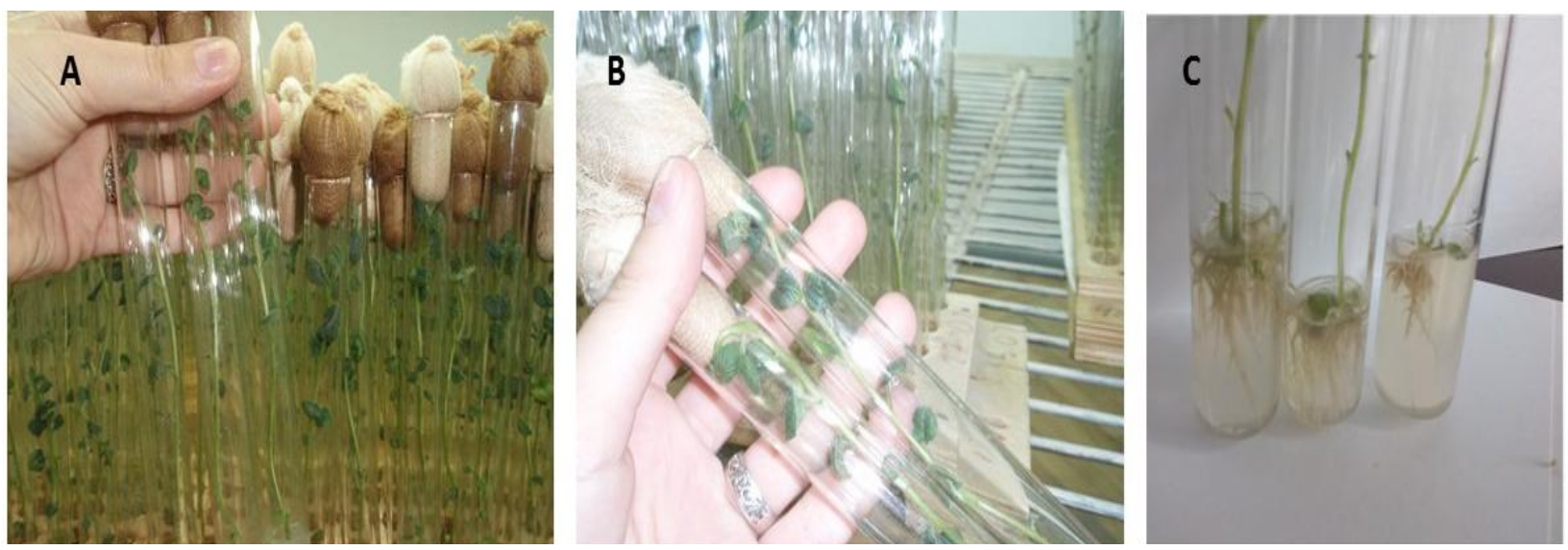

Figure 2:- Effect of growth hormones combination IBA $(0.1 \mathrm{mg} / \mathrm{l}) / \mathrm{BAP}(1 \mathrm{mg} / \mathrm{l})$ on two potato cultivar's (Zefira, Riviera) in vitro propagation. A-Root and shoot formation after 4 weeks (Zefira); B-Root and shoot formation after 4 weeks (Riviera); C-Root formation after 4 weeks (Zefira).

Concentration of IBA was increased on the next stage (from $0.05 \mathrm{mg} / \mathrm{l}$ to $0.1 \mathrm{mg} / \mathrm{l}$ ), High concentration of IBA was not effectiveon in vitro development in all three cultivars: Zefira, Nevsky, Riviera (Table 3).

According to the results three potato cultivars had variable in vitro growing on all experimental MS medium. $6 \%$ MS medium $+1 \mathrm{mg} / \mathrm{l} \mathrm{BA}+0,1 \mathrm{mg} / \mathrm{l} \mathrm{IBA}$ wasn't effective neither of potato cultivars, $1 \mathrm{mg} / \mathrm{l} \mathrm{BA}+0,1 \mathrm{mg} / \mathrm{l} \mathrm{IBA}$ wasn't effective neither of potato cultivars, Zefira and Riviera gave their maximum in vitro regeneration perexplant on $6 \%$ MS medium $+1 \mathrm{mg} / \mathrm{l} \mathrm{BAP}+0,05 \mathrm{mg} / \mathrm{lIBA}$. Nevsky revealed perfect in vitro development onMS medium+ $30 \mathrm{~g} / \mathrm{l}$ sucrose without growth hormones.

Table 3:- The effect of cytokinesIBA $(0.1 \mathrm{mg} / \mathrm{l})$ and auxin BAP $(1 \mathrm{mg} / \mathrm{l})$ in vitro potato shoot and root formation

\begin{tabular}{|c|c|c|c|c|c|c|c|}
\hline $\begin{array}{c}\text { potato } \\
\text { Cultivars }\end{array}$ & Type of plant & Shoot length $(\mathrm{mm})$ & $\begin{array}{c}\text { Shoot } \\
\text { thickness } \\
(\mathrm{mm})\end{array}$ & $\begin{array}{l}\text { Nodes } \\
\text { per } \\
\text { plant }\end{array}$ & $\begin{array}{l}\text { Root } \\
\text { length } \\
(\mathrm{mm})\end{array}$ & Root formation(\%) & $\begin{array}{c}\text { Shoot } \\
\text { formation(\%) }\end{array}$ \\
\hline \multicolumn{8}{|c|}{$6 \% \mathrm{MS}$ medium $+1 \mathrm{mg} / \mathrm{l} \mathrm{BA}+0,1 \mathrm{mg} / \mathrm{lBA}$} \\
\hline Nevsky & in vitro plant & 46.15 & 0.77 & 3 & 9.56 & 38.7 & 24.89 \\
\hline Riviera & in vitro plant & 42.76 & 0.69 & 3 & 8.24 & 38 & 23.56 \\
\hline Zefira & in vitro plant & 100 & 1.64 & 6 & 12.3 & 79.7 & 78.4 \\
\hline
\end{tabular}

\section{Discussions:-}

Auxin/ cytokine combinations effect on plant growth depend on the plant genotype, their chemical consistent and physiological statement. Auxin/ and cytokine interaction may be interrelated, simultaneous or antagonistic,in most cases their molecular interaction mechanism is not fully studied (Coenen and Lomax, 1997).

Cytokines and auxins possess (cross talk) stimulation action and they play leading role in plant micro propagation, but sucrose together with phytohormones have an important role in regulation of morphogenesis (Negrutiuat all., 1987). 
The result of research suggested that $1 \mathrm{mg} / \mathrm{l}$ BAP had a positive effect and an important role in plant differentiation process, which was expressed in great formation (shoots and root) of in vitro plant. High concentration of IBA $(0.1 \mathrm{mg} / \mathrm{l})$ results in plant root thickness, it is undesirable for plant. When we used auxin low concentration of $(0.05 \mathrm{mg} / \mathrm{l})$ actively growing of root meristem took place, this is confirmed by our result (normal and excellent formation of root).

In conclusion, both hormones combination presented in experiment with $30 \mathrm{~g} / \mathrm{l}$ sucrose showed optimalresult on in vitro growing potato cultivars Zefira and Riviera, but best in vitro cultivation of Nevsky was revealed MS medium supplemented only $30 \mathrm{~g} / \mathrm{l}$ sucrose without growth hormones, probably this resultdepends on Nevsky's genotypes, it seems Nevsky has ability to produce itself the amount of hormones which is necessary it's normal growing.

\section{Acknowledgements:-}

The authors acknowledged tothe PhD student Nino Murvanidze Plant Production Faculty of Bioscience Engineering Ghent University Coupure links 653, 9000 Gent, Belgium for professional support to carry out this work.

\section{References:-}

1. Badoni A, Chauhan, J S.(2009).Effect of Growth Regulators on Meristem-tip Development and in vitro Multiplication of Potato Cultivar 'KufriHimalini, Nature and Science, 7(9):31-34.

2. Coenen C, Lomax, TL. (1997).Auxin-cytokinin interactions in higher plants: old problems and new tools. Trends Plant Scince, 2: 351-356.

3. Espinoza N, Estrada R, Tovar P, Bryan J, Dodds JH. (1986).Tissue Culture Propagation of Potato. CIP slide Training series 1-5 Int. Potato center, Dept. of training and communications, P. O. Box. 5659, Lima, Peru.

4. FAOstatisticaldatabase.(2016).http://www.fao.org/corp/statistics/en/ read on29.02.2016.

5. Islam MS, Chowdhury AR. (1998). Virus freestock production of some indigenous potato varietiesof Bangladesh. Plant Tissue Culture, 8(1): 41-47.

6. Karim MR. (2009). Seed potato production and tissue culture technology in Bangladesh. Seminar On: Seed potato production and tissue culture technology in Bangladesh. Organized by Bangladesh Agricultural Development Corporation (BADC), Dhaka, Bangladesh.

7. Kaur M, Kaur R, Sharma Ch, Kaur N, Kaur A.(2015). Effect of growth regulators on micropropagation of potato cultivars. African Journal of Crop Science ISSN 2375-1231 Vol. 3 (5), pp. 162-164, Available online at www.internationalscholarsjournals.org (C) International Scholars Journals.

8. Khadiga G. AbdElaleem, Rasheid S. Modawi and Mutasim, Khalafalla, M. (2009). Effect of Cultivar and Growth Regulator on in vitroMicropropagation of Potato (Solanum tuberosumL), Am-Eurasian J.Sustain. Agric, 1(1): 1-7.

9. Khan MS, Hoque RH, Sarker H, Muehlebach P. (2003). Detection of important plant viruses in in vitro regenerated potato plants by double antibody sandwich method of ELISA. Plant Tissue Culture, 13(1): 21-29.

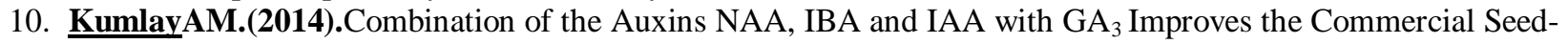
Tuber Production of Potato (Solanum tuberosum L.) under In Vitro Conditions. BioMed Research International, Volume 2014; Article ID 439259, 7 pages.

11. Liljana KG, Mitrev S, Fidanka T, Mite I. (2016).Micropropagation of Potato- Solanum tuberosumL. Electr. J. Biol, 2012; 8(3): 45-49.

12. Morariu A, Dascalu MC, Ciobotari G, Gradinariu G. (2010). Influence of the Genotype and the Auxine/Citokinine Balance on the in vitro Morphogenetic Response at Raspberry and Blackberry Varieties,U.A.S.V.M. Iasi, M. Sadoveanu Alley, No. 3,700490, Iasi, Romania, 28th International Horticultural Congress - IHC Lisboa (22 a 27 de Agosto).

13. Naik PS, Sarkar D. (2000).In vitro propagation and conservation of genetic resources in potato. In: K.L. Chadha, P.N. Ravindran and S. Leela (eds) Biotechnology in Horticultural and Plantation Crops, Malhotra Publishing House, New Delhipp: 369-406.

14. Negrutiu I, Jacobs M, De Greef W.(1987).In vitro morphogenesis of Arabidopsis thaliana the origin of exsplant, ZeitschriftfürPflanzenphysiologie, Volume 90, Issue 4, pp363-372.

15. Wang PJ, Hu CY. (1982).In vitro mass tuberization and virus-free seed potato production in Taiwan. AmPoJ. 59: 33-37. 